\title{
Peningkatan Aktivitas Dan Hasil Belajar Kognitif melalui Model STAD disertai Mind Mapping
}

\section{Improving Students' Activeness and Cognitive Learning Outcomes by using STAD and Mind Mapping}

\author{
Papin Citra Resti Rustanto $^{1^{*}}$, Yudi Rinanto ${ }^{1}$, Nurmiyati $^{1}$ \\ ${ }^{1}$ Pendidikan Biologi, Fakultas Keguruan dan Ilmu Pendidikan, Universitas Sebelas Maret. Jl. Ir. Sutami No.36A, Jebres, Kota Surakarta, \\ Jawa Tengah 57126, Indonesia \\ *Corresponding authors: papin.rustanto@gmail.com
}

Manuscript received:

Revision accepted:

\begin{abstract}
This research aims at improvement the learning activity and the concept achievement through the use of STAD Model with Mind Mapping. This research is a classroom Action Research conducted into two cycles, from February 2016 to March 2016. Each cycle consist of four stages, namely Planning, Acting, Observing, and Reflecting. The research subject is 31 students of class XI MIPA 4 at SMA Negeri 6 Surakarta in the Academic Year of 2015/2016. The data art obtained from the observation, test, questionnaires, interview, and documentation. The data about the learning activities includes visual activities, oral activities, listening activities, writing activities, drawing activities, and emotional activities, measured by the observation field notes. The concept achievement is measured by using a cognitive test in the form of an objective test of multiple choices. The data art analysed by using descriptive analysis technique. The validity is measured by using triangulation technique. The research procedures are conducted by using spiral Kemmis and Mc. Targart. Target of the study is $25 \%$ of the base line. Through the observation, the research can enhancement of precycle to cycle II has increased. The analysis of the research show that the visual activity increased from $25,81 \%$ to $96,77 \%$, oral activities increased from $22,58 \%$ to $90,32 \%$, listening activities increased from $45,16 \%$ to $93,55 \%$, writing activities increased from $67,74 \%$ to $70,79 \%$, drawing activities increased from $9,68 \%$ to $90,32 \%$, motor activities increased from $0 \%$ to $83,87 \%$, mental activities increased from $35,48 \%$ to $67,74 \%$, emotional activities increased from $32,26 \%$ to $93,55 \%$, the concept test increased from $25,81 \%$ to $87,1 \%$.
\end{abstract}

Keywords: STAD model, Mind Mapping, Learning of Activity and Concept Achievement.

\section{PENDAHULUAN}

Tujuan belajar akan tercapai apabila guru dapat mengarahkan siswa kepada tujuan belajar sesuai dengan harapan. Pembelajaran yang sesuai adalah dengan berorientasi pada aktivitas belajar siswa, siswa sebagai pusat pembelajaran. Observasi proses pembelajaran selama kegiatan PPL di kelas XI MIPA 4 SMA Negeri 6 Surakarta menunjukkan bahwa guru masih mendominasi pembelajaran. pembelajaran yang berlangsung menekankan penguasaan materi sebanyak-banyaknya dari guru kepada siswa. Pembelajaran cenderung berlangsung satu arah dengan guru sebagai peran utama di dalam kelas.

Proses pembelajaran berlangsung dengan metode ceramah, latihan dan penugasan diberikan untuk dikerjakan di rumah. Selama pembelajaran, guru tidak menggunakan media atau alat peraga. Perhatian guru terpusat pada siswa yang duduk dibarisan depan. Penggunakan bahan ajar belum maksimal. Kegiatan pembelajaran di dalam kelas menjadi terbalik dari harapan kurikulum 2013, karena guru aktif memberikan materi sedangkan siswa pasif menerima materi dengan menjadi pendengar. Dengan kata lain pembelajaran yang terjadi tidak berpusat kepada siswa, tidak berorientasi pada aktivitas belajar siswa.
Kelas ini memiliki karakter aktivitas yang jauh dari standar aktivitas pembelajaran yang diharapkan pada Kurikulum 2013. Pembelajaran yang diharapkan adalah pembelajaran yang berorintesi pada aktivitas belajar siswa sehingga akan memberikan kesan dan makna dalam benak siswa. Siswa belajar untuk membentuk pemahaman sendiri melalui interaksi dengan sumber belajar yang digunakan. Pembelajaran dengan metode ceramah hanya mampu memberikan pemahaman konsep jangka pendek, gagal untuk memberikan pemahaman konsep jangka panjang pada siswa. Ketercapaian proses pembelajaran terletak pada siswa, dengan kata lain bahwa siswa sebagai pusat pembelajaran.

Berdasarkan hasil observasi dan angket pra siklus, di dapatkan data aktivitas siswa yang masih tergolong rendah. Hasil analisis menunjukkan visual activities 8 siswa $(25,81 \%)$, oral activities 7 siswa $(22,58 \%)$, listening activities 14 siswa (45,16\%), writing activities 21 siswa $(67,74 \%)$, drawing activities 3 siswa $(9,68 \%)$, motor activities 0 siswa (0\%), mental activities 11 siswa $(35,48 \%)$, emotional activities 10 siswa $(32,26 \%)$.

Lebih jauh melihat nilai pemahaman konsep kelas ini, KKM yang ditetapkan sekolah, yaitu 2,67 dengan skala 4 
belum dapat tercapai. Masih banyak siswa yang tidak tuntas, 8 siswa yang dapat melampaui standar KKM. Aktivitas belajar di dalam kelas membuat siswa kurang fokus pada pembelajaran. Informasi yang disampaikan guru tidak sepenuhnya dapat diterima siswa. Siswa kedapatan mengantuk saat pembelajaran, siswa tersebut tidak memperhatikan apa yang dijelaskan guru, saat menerima penjelasan posisnya tiduran pada meja. Rasa bosan dan jenuh terhadap proses pembelajaran menimbulkan sikap siswa yang seharusnya tidak dilakukan dalam menerima pelajaran. Keterlibatan siswa dalam proses pembelajaran yang kurang membuat siswa bersikap pasif, hal ini mengakibatkan nilai pemahaman konsep siswa yang rendah.

Solusi yang ditawarkan untuk menghadapi permasalahan pembelajaran kelas XI MIPA SMA Negeri 6 Surakarta adalah menerapkan model pembelajaran kooperatif. Wina (2008:242) mengemukakan dua alasan bahwa: pembelajaran kooperatif merupakan bentuk pembelajaran yang dapat memperbaiki pembelajaran selama ini. Pertama, beberapa penelitian membuktikan bahwa penggunaan pembelajaran kooperatif dapat meningkatkan prestasi belajar siswa sekaligus dapat meningkatkan kemampuan hubungan sosial, menumbuhkan sikap menerima kekurangan diri dan orang lain, serta dapat meningkatnya harga diri. Kedua, pembelajaran kooperatif dapat merealisasikan kebutuhan siswa dalam belajar, berfikir, memecahkan masalah dan mengintegrasikan pengetahuan dengan keterampilan.

Pembelajaran Kooperatif tipe STAD dikembangkan oleh Robert Slavin ini merupakan modelpembelajaran kooperatif yang paling sederhana, sehingga cocok untuk digunakan bagi guru baru mulai menggunakan pembelajaran kooperatif. Selain itu juga dapat membantu menumbuhkan kompetensi siswa, berpikir kritis dan mengembangkan sikap sosial sehingga meningkatkan motivasi, dan aktivitas belajar siswa (Harhap, 2013).Penerapan STAD akan disertai dengan Mind Mapping. Mind Mapping merupakan cara paling mudah untuk memasukkan informasi ke dalam otak. Bentuk Mind Mapping yang digunakan sebagai catatan siswa dapat memberikan kemudahan dalam berpikir dan meningkatkan pemahaman terhadap materi. Keduanya jika digabungkan tidak akan membebani guru dan siswa karena merupakan model yang paling sederhana dan mudah.

Minimnya tingkat keterlibatan siswa dalam pembelajaran biologi mengakibatkan keterampilan proses sains siswa kurang terlatih. Pembelajaran biologi yang ada seharusnya lebih menekankan pada keterampilan proses sains. Sependapat dengan Sardiman (2009:96), menegaskan bahwa anak-anak memiliki tenaga-tenaga untuk berkembang sendiri, membentuk sendiri. Pendidik akan berperan sebagai pembimbing dan mengamati bagaimana perkembangan anak-anak didiknya.

Kelebihan model STAD menurut Slavin (2005): (1) meningkatkan kecakapan individu, (2) mengkatkan kecakapan kelompok, (3) meningkatkan komitmen, (4) menghilangkan prasangka buruk terhadap teman sebaya, (5) tidak bersifat kompetitif, (6) tidak memiliki rasa dendam. Kekurangan: (1) kontribusi dari siswa berprestasi rendah menjadi kurang, (2) siswa berprestasi rendah akan mengarah pada kekecewaan karena para anggota yang pandai lebih dominan, (3) Waktu yang dibutuhkan dalam pembelajaran lebih lama. Pembelajaran kooperatif yang dikemas dalam kegiatan pembelajaran bervariasi dengan model STAD dapat menumbuhkan motivasi dan prestasi belajar siswa. Keberhasilan anggota merupakan tugas bersama. Pembelajaran rumpun ilmu pengetahuan alam, dalam hal ini Biologi disamping memberikan materi berupa konsep juga terdapat kompetensi keterampilan. Untuk kepentingan penguasaan kompetensi dan keterampilan maka penggunaan pembelajaran kooperatif STAD tepat untuk digunakan. STAD merupakan model pembelajaran kooperatif yang paling sederhana, dan merupakan model paling baik untuk permulaan bagi para guru baru menggunakan pendekatan kooperatif.

Model pembelajaran kooperatif ini dikembangkan berdasarkan teori belajar kognitif-konstruktivis. Pada proses pembelajaranya, pembelajaran kooperatif tipe $S T A D$ peserta didik melalui lima tahapan yang meliputi tahap penyajian materi, tahap kegiatan kelompok, tahap tes individual, tahap penghitungan skor perkembangan individu, dan tahap pemberian penghargaan kelompok. Penghargaan diberikan kepada Super team, great team, dan good team (Slavin, 2008).

Dalam kegiatan pembelajaran dengan penerapan model STAD siswa didorong untuk bertanggung jawab terhadap proses belajar lebih besar karena siswa lebih banyak bekerja dari pada sekedar mendengarkan informasi sehingga model ini dapat melatih tanggung jawab siswa selama proses belajarnya. Pengalaman sosial dalam kerja kelompok mengharuskan setiap siswa untuk mau berpendapat dan menceritakan dengan jelas sesuai pemahamannnya kepada siswa lain dalam kelompok. Siswa lain dalam kelompok dapat menulis ulang apa yang sudah dijelaskan atau mengkoreksi pemahaman tersebut sehingga terdapat kesimpulan yang sama. guru yang dipindahtangankan kepada siswa, tetapi berupa informasi yang diterima oleh siswa dan merupakan bukti dari pemahaman siswa terhadap materi yang dipelajari.

Slameto (2009) menyatakan bahwa salah satu cara belajar yang efektif adalah siswa harus dapat membuat catatan. Mind mapping adalah cara belajar kreatif untuk siswa yang dikembangkan oleh Tony Buzan. Mind mapping bertujuan untuk menghasilkan tulisan tangan berupa catatan, didalamnya merupakan gagasan dan informasi apa yang telah dipelajari atau sebuah perencanaan tugas yang baru. Konsep mind mapping adalah penggunaan citra visual atau mengikuti pikirann otak, sehingga memberikan detail-detail yang mudah diingat. Ristiasari (2012) menyatakan bahwa kemampuan siswa dalam berpikir juga dapat dilatih melalui penugasan untuk membuat mind mapping.

Penggunaan LKS disertai mind mapping menjadi inovasi bahan ajar yang dapat digunakan untuk meningkatkan hasil belajar siswa. Melihat kelebihan mind mapping dapat membantu siswa dalam mengingat, mendapatkan ide, menghemat waktu, berkonsentrasi, 
mendapatkan nilai yang bagus, mengatur pikiran dan hobi, media bermain, bersenang-senang dalam menuangkan imajinasi yang akan memunculkan kreativitas. Perlu diingat pula dalam menggunkaan mind mapping akan ada waktu yang terbuang untuk menuliskan kata-kata yang tidak memiliki hubungan dengan ingatan, waktu terbuang untuk membaca kata-kata yang tidak perlu, hubungan kata kunci pengingat terputus oleh kata - kata yang memisahkan, kata kunci pengingat terpisah oleh jarak. Indriani (2008) dalam Ristiasari (2012:35) menyatakan bahwa mind mapping merupakan strategi pembelajaran yang mengembangkan kemampuan otak kiri dan otak kanan dengan menggambarkan hal yang bersifat umum kemudian baru yang bersifat khusus dalam peta.

Berdasarkan uraian Model STAD dan mind mapping, keduanya akan saling melengkapi jika digunakan dalam pembelajaran. Mind mapping yang menyertai penerapan model STAD diletakkan pada penggunaan LKS. Penggunaan mind mapping pada LKS akan menyebabkan proses belajar yang menyenangkan dan mendorong siswa untuk berkreativitas. Hal ini secara tidak langsung akan meningkatkan pemahaman siswa terhadap materi yang diberikan.

Atas dasar tersebut, maka perlu dilakukan penelitian, yaitu: "Peningkatan Aktivitas dan Hasil Belajar Kognitif melalui Model STAD disertai Mind Mapping"

\section{METODE PENELITIAN}

Penelitian dilakukan di kelas XI MIPA 4 SMA Negeri 6 Surakarta. Terletak di jalan Mr. Sartono nomor 30 Surakarta. Kelas XI SMA Negeri 6 Surakarta terdiri dari 4 Kelas XI MIPA, 4 kelas XI IPS, dan 1 kelas XI Bahasa. KKM untuk mata pelajaran biologi adalah 2,67. SMA Negeri 6 Surakarta termasuk dalam tingkatan cluster bawah di berdasarkan nilai NEM masuk seleksi penerimaan saringan masuk peserta didik SMA Negeri Surakarta.

Bentuk penelitian ini adalah Penelitian Tindakan Kelas (PTK) atau Classroom Action Research (CAR) yang bertujuan untuk meningkatkan keterampilan proses sains dalam pembelajaran biologi. Prosedur dan langkah-langkah dalam penelitian tindakan kelas ini mengikuti model yang dikembangkan oleh Kemmis dan Mc.Taggart (2005) berupa model spiral yaitu dalam satu siklus terdiri dari tahap perencanaan, tindakan, observasi, dan refleksi.

Tahap perencanaan pembelajaran meliputi penyusunan instrumen pembelajaran dan instrumen penelitian. Instrumen pembelajaran terdiri dari silabus, RPP, LKS, dan materi ajar, sedangkan instrumen penelitian terdiri dari lembar observasi, soal keterampilan proses sains, lembar observasi keterlaksanaan sintak, dan pedoman wawancara, serta peralatan dokumentasi.

Data penelitian keterampilan proses sains siswa diperoleh melalui observasi, tes tertulis, wawancara, dan dokumentasi. Observasi dan dokumentasi dilakukan selama pelaksanaan tindakan dengan melakukan check $(\sqrt{ })$ pada lembar observasi keterampilan proses sains, sedangkan tes tertulis dan wawancara dilaksanakan di setiap akhir pembelajaran.
Berbeda dengan mencatat dalam format kalimat dan alinea, mind mapping berujud diagram atau peta yang bersifat radial, yakin sesuatu yang mirip jari-jari lingkaran atau sesuatu yang berpendar seperti sinar. Bentuk lingkaran atau pendaran sinar tentu bermula dari sebuah titik yang kemudian melebar dan membesar atau berpendar. Demikian pula wujud mind mapping itu, peta atau diagram mind mapping selalu berpusat dari sebuah konsep, kata, frasa, atau ide yang dituliskan di titik tengah selembar kertas. Kemudian, dari titik tengah itulah dibuat cabangcabang ke arah lingkaran luar yang berupa kata-kata, frasa, konsep, atau ide yang semuanya masih memiliki relevansi dan keterkaitan dengan konsep awal di titik tengah itu. Lalu, antar konsep, kata, frasa, atau ide itulah dihubungkan tanda garis yang dimulai dari garis tebal di tengah berubah menjadi garis yang lebih tipis ke luar lingkaran. Dengan fokus pada konsep atau ide utama di titik tengah (pusat) lalu kemudian mengembangkannya dalam bentuk cabangcabang yang saling terhubung.

\section{HASIL PENELITIAN DAN PEMBAHASAN}

Skor capaian aktivitas belajar siswa berdasarkan hasil observasi pada pra siklus, siklus 1 , siklus 2 pertemuan pertama, dan siklus 2 pertemuan kedua dapat dilihat pada Tabel 1.

Tabel 1. Skor Capaian Aktivitas Belajar Siswa

\begin{tabular}{|c|c|c|c|c|}
\hline \multirow[t]{2}{*}{ Aspek } & \multicolumn{4}{|c|}{ Capaian aspek (\%) } \\
\hline & $\begin{array}{c}\text { Pra } \\
\text { siklus }\end{array}$ & $\begin{array}{c}\text { Siklus } \\
\text { I }\end{array}$ & $\begin{array}{l}\text { Siklus } \\
\text { II (1) }\end{array}$ & $\begin{array}{l}\text { Siklus } \\
\text { II (2) }\end{array}$ \\
\hline Visual & 25,81 & 64,52 & 80,65 & 96,77 \\
\hline Oral & 22,58 & 61,29 & 70,97 & 90,32 \\
\hline Listening & 45,16 & 29,03 & 74,20 & 93,55 \\
\hline Writing & 67,74 & 6,45 & 38,71 & 70,97 \\
\hline Drawing & 9,68 & 19,36 & 61,29 & 90,32 \\
\hline Motor & 0 & 74,19 & 58,06 & 83,87 \\
\hline Mental & 35,48 & 9,68 & 29,02 & 67,74 \\
\hline Emotional & 32,26 & 61,29 & 67,74 & 93,55 \\
\hline
\end{tabular}

Tabel 1 menunjukkan capaian skor tiap aspek aktivitas belajar siswa dari tahap pra siklus, siklus I, siklus II, dan siklus III. Skor tersebut menunjukkan adanya peningkatan aktivitas belajar siswa di akhir siklus dibandingkan dengan pra siklus, siklus I, dan siklus II. Hasil pengukuran keterampilan proses sains siswa di akhir tindakan menunjukkan bahwa sebagian besar aspek sudah mencapai target akhir, namun terdapat satu aspek yang belum mencapai target akhir yaitu writing activity. Berdasarkan Tabel 1 dapat dilihat tingkat kenaikan skor tiap aspek aktivitas belajar yang disajikan dalam bentuk diagram pada Gambar 1 


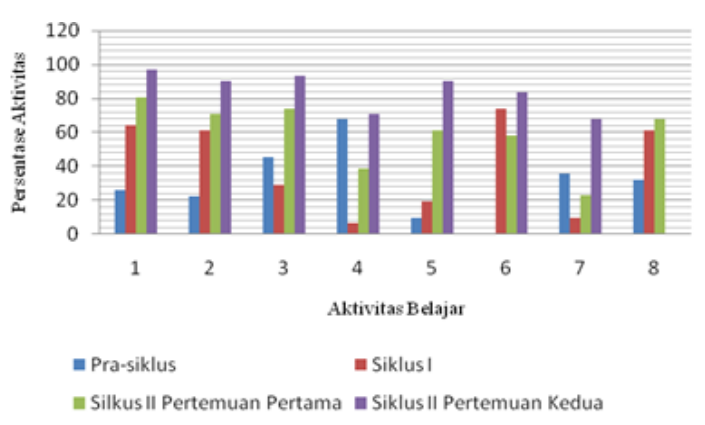

Gambar 1. Peningkatan Skor Tiap Aspek Aktivitas Belajar

Peningkatan terjadi mulai dari siklus I, siklus II pertemuan pertama, dan siklus II pertemuan kedua baik dari tiap aspek maupun rata-rata keseluruhan aspek.

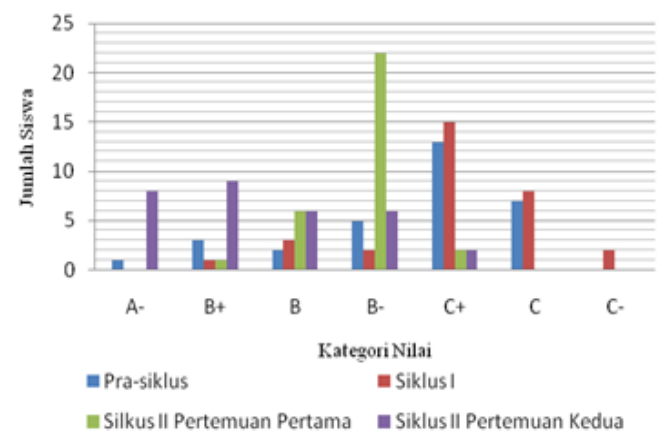

Gambar 2. Peningkatan Hasil Belajar Kognitif Siswa Pra siklus, siklus I, II Pertemuan Pertama, dan II Pertemuan Kedua

Berdasarkan Gambar 2. grafik hasil belajar kognitif siswa dari kegiatan Pra-Siklus sampai Siklus II memiliki bentuk hampir mirip. Persebaran jumlah siswa terjadi pada kategori B- dan $\mathrm{C}+$. Terjadi penurunan hasil belajar pada kegiatan Pra-Siklus ke Siklus I sebanyak 4 siswa dari 8 menjadi 4. Pada Siklus II pertemuan pertama, jumlah siswa yang tuntas sebanyak 21 siswa. Pada Siklus II pertemuan kedua jumlah siswa yang tuntas naik menjadi 27 siswa.

Persentase ketuntasan siswa berdasarkan hasil observasi mengalami fluktuasi dari penurunan lalu terjadi peningkatan. pada kegiatan Pra-Siklus sebesar 25,81\%. Pada Siklus I persentase turun menjadi 12,9\%. Peningkatan persentase terjadi pada Siklus II pertemuan pertama sebanyak 54,84\% menjadi 67,74\%. Selanjutnya pada Siklus II pertemuan kedua ketuntasan siswa mengalami peningkatan sebanyak 19,36\% menjadi 87,1\%. Berdasarkan hasil belajar kognitif siswa, target penelitin sebesar 50,81\% sudah terpenuhi.

Aktivitas siswa terbesar di dalam kelas adalah menulis catatan. Proses pembelajaran belum mengakomodasi siswa untuk melakukan aktivitas lebih dari menulis, siswa menulis catatan yang sama persis dengan catatan guru. Siswa merasa bosan dengan cara guru memberikan materi pembelajaran. Aktivitas siswa ketika bosan ditunjukkan dengan diam dengan posisi malas, berbincang dengan teman, bermain handphone, menggambar bebas di buku atau tempat lain.

Penggunaan metode ceramah kurang menarik di terapkan pada siswa SMA terutama dalam pelajaran Biologi. Siswa merasa bosan, malas, dan tidak dapat menerima pelajaran dengan maksimal. Siswa belum terbiasa membaca buku referensi sendiri atau mengungkapkan kebingungan dalam pendapat dan pertanyaan saat pembelajaran. Aktivitas diskusi siswa belum tampak pada kegiatan pembelajaran. Pembelajaran yang diinginkan siswa terbanyak yaitu: diskusi dan sejenis kuia atau lomba, dengan metode visualisasi yang menarik, dengan gaya belajar sesuai dengan ide siswa dan guru. Berdasarkan permasalahan pada kegiatan pra-Siklus maka perlu dilakukan tindakan untuk meningkatkan aktivitas siswa dan meningkatkan hasil belajar kognitif siswa di dalam pembelajaran Biologi.

Berdasarkan hasil dan analisis hasil penelitian pada siklus I dan siklus II diketahui bahwa penerapan model pembelajaran STAD disertai Mind Mapping dapat meningkatkan aktivitas dan hasil belajar kognitif siswa. Kondisi Pra-siklus di kelas XI MIPA 4 SMA N 6 Surakarta menunjukkan bahwa siswa belum dilibatkan secara optimal untuk membangun konsep sendiri melalui kegiatan pembelajaran. Aktivitas siswa yang paling menonjol adalah writing activity, ditunjukkan dengan menulis catatan. Aktivitas tersebut dilakukan hampir seluruh siswa yang ada di kelas. Siswa terbiasa mencatat apa yang diucapkan dan ditulis guru. Tidak terlihat aktivitas motorik seperti: diskusi, menganalisa permasalahan, menyimpulkan materi, dan mempresentasikan hasil kerja. Metode yang digunakan guru dalam proses pembelajaran adalah ceramah, akibatnya siswa menjadi bosan, mudah mengantuk, dan pasif. Keadaan tersebut bila tidak segera diatasi akan berdampak pada rendahnya aktivitas dan hasil belajar siswa.

Hasil belajar siswa kegiatan Pra-siklus menunjukkan bahwa kognitif siswa tergolong rendah. Sekolah menggunakan KKM 2,67 mengacu pada standar Kurikulum 2013 dengan nilai skala 4. Siswa dinyatakan tuntas jika nilai yang diperoleh adalah 2,67 atau melampaui. Hasil UTS siswa yang digunakan sebagai base line penelitian sebanyak 8 siswa yang tuntas. Jumlah ini belum dapat dikatakan bahwa kelas XI MIPA 4 lulus secara klasikal. Standar kelas lulus dalam nilai kognitif jika 85\% siswa di dalam kelas dapat menyerap sebesar $75 \%$.

Tindakan untuk meningkatkan aktivitas dan hasil belajar siswa kelas XI MIPA 4 SMA N 6 Surakarta pada penelitian ini adalah melalui penerapan model STAD disertai mind mapping. Peran guru dalam pembelajaran yaitu: menyampaikan tujuan pelajaran, menyajikan informasi dengan demonstrasi atau bahan bacaan, cara membentuk kelompok belajar, membimbing kelompok belajar, mengevaluasi hasil belajar, mencari cara untuk menghargai baik individu mupun kelompok. Siswa lebih dituntut lebih aktif dari guru. terbukanya kesempatan untuk berproses dalam pembelajaran diharapkan aktivitas dan hasil belajar siswa dapat meningkat.

Kegiatan Siklus I dilaksanakan pada tanggal 23 Maret 2016. Proses belajar mengajar dimulai tepat pukul 06.30 
WIB dengan mata pelajaran pertama Biologi. Materi yang digunakan adalah Sistem Koordinasi dengan subtopik Sistem Hormon. Awal kegiatan pembelajaran di buka dengan doa dan menyanyikan Indonesia Raya. Waktu yang dihabiskan untuk memulai pembelajarn 5 menit. Kegiatan selanjutnya guru mengunakan pedoman sintak dari peneliti dengan model STAD dan mind mapping. Terlihat perbedaan antara kegiatan pembelajaran Pra-siklus dan Siklus I. Siswa yang biasa diam dan pasif pada kegiatan Siklus I dituntut untuk mengikuti arah guru.

Kegiatan siswa diawali dengan mengamati gambar, membandingkan, dan mengemukakan pendapat. Tahap selanjutnya siswa diminta untuk membentuk kelompok, berpindah tempat, dan berdiskusi. Pada kegiatan Pra-siklus siswa cenderung menulis atau writing activity siswa lebih menonjol daripada aktivitas yang lain, Siklus I aktivitas siswa yang menonjol adalah motorik.

Hal ini dapat dilihat dari pergerakan siswa untuk berpindah tempat mencari kelompoknya, mengambil buku atau referensi yang dapat digunakan, mencari peralatan untuk menyelesaikan puzzel, dan maju ke depan kelas untuk melakukan presentasi. Motor activity siswa meningkat melalui aktivitas diskusi. Siswa dituntut untuk berperan aktif dalam diskusi, baik untuk berpindah tempat, menentukan buku yang akan dibaca, membagi pembahasan, menuliskan hasil diskusi, dan melakukan presentasi. Keterlibatan siswa dalam diskusi diamati oleh observer tiap kelompok.

Aktivitas baru yang dilakukan mendorong siswa untuk lebih aktif bergerak dan mencoba. Berkebalikan dengan kegiatan Pra-siklus dimana siswa aktif mencatat, pada kegiatan Siklus I siswa cenderung meninggalkan kebiasaan lama untuk menulis catatan. Adaptasi siswa dalam mengikuti sintak model STAD disertai mind mapping mengubah kebiasaan siswa yang pasif dan mencatat apa yang diucapkan guru. Berdasarkan hasil observasi aktivitas, writing activity pada kegiatan Siklus I memiliki persentase yang rendah dan cenderung turun dari kegiatan Pra-siklus.

Hasil belajar kognitif siswa pada kegiatan Siklus I memiliki persentase $12,9 \%$ atau sebanyak 4 siswa yang tuntas. Hasil ini menggambarkan bahwa siswa belum terbiasa dengan model pembelajaran selain ceramah. Siswa terfokus pada kegiatan pengamatan, diskusi, presentasi, bertanya, namun materi yang disampaikan tidak diperhatikan sungguh-sungguh. Waktu yang diberikan guru untuk mengerjakan juga mempengaruhi siswa mampu mengerjakan semua soal yang diberikan. Dengan waktu 5 menit tidak banyak siswa yang mampu menyelesaikan soal tes. Jawaban siswa Siklus I belum maksimal, kecenderungan siswa menuliskan kembali apa yang pada catatan membuat siswa lemah dalam mengerjakan soal. Siswa terbiasa menghafal apa yang sudah tercatat dalam buku catatan, tidak terbiasa menggunakan kata-kata sendiri untuk menerjakan soal tes.

Pada Siklus I hasil belajar kognitif siswa sebagai berikut: kategori $\mathrm{B}+$ sebanyak 1 siswa atau 3, 23\%, kategori B sebanyak 3 siswa atau 9,68\%, kategori B- sebanyak 2 siswa atau $6,45 \%$, kategori $\mathrm{C}+$ sebanyak 15 siswa atau
48,39\%, kategori C sebanyak 8 siswa atau 25,80\%, dan kategori C-sebayak 2 siswa atau 6,45\%. Siswa dinyatakan tuntas jika nilai kognitif yang diperoleh 2,67 atau lebih.

Siklus II pertemuan pertama hasil belajar kognitif siswa sebagai berikut: kategori $\mathrm{B}+$ sebanyak 1 siswa atau 3,23\%, kategori B sebanyak 6 siswa atau 19,35\%, kategori Bsebanyak 22 siswa atau 70,97\%, kategori $\mathrm{C}+$ sebanyak 2 siswa atau $6,45 \%$. Siklus II pertemuan kedua hasil belajar kognitif siswa sebagai berikut: kategori A- sebanyak 8 siswa atau $25,80 \%$, kategori $\mathrm{B}+$ sebanyak 9 siswa atau $29,03 \%$, kategori B sebanyak 6 siswa atau 19,35\%, kategori B- sebanyak 6 siswa atau 19,35\%, kategori C+ sebanyak 2 siswa atau $6,45 \%$. Jumlah siswa yang tuntas pada Siklus II pertemuan kedua sebanyak 27 siswa.

Kegiatan Siklus II dilaksanakan satu minggu setelah Siklus I dilaksanakan. Proses belajar mengajar dimulai pukul 06.30 WIB. Siklus II menggunakan materi sistem koordinasi dengan subtopik alat indra. Pertemuan pertama membahas lidah,mata dan hidung. Pertemuan kedua membahas telinga dan kulit. Pembukaan dilakukan oleh siswa secara bergantian. Guru memulai pembelajaran dengan demonstrasi alat indra. Kegiatan Siklus II pertemuan pertama visual activity memiliki persentase tertinggi dari aktivitas yang lain. Kegiatan Siklus II siswa difokuskan untuk mengamati apa yang terjadi dengan siswa lain sebagai perwakilan, cukup beralasan jika aktivitas siswa cenderung tinggi pada aspek visual.

Adaptasi siswa terhadap penerapan model STAD disertai mind mapping pada Siklus II lebih baik daripada Siklus I. Hasil observasi aktivitas siswa meningkat dibanding Siklus I. Siswa terlihat lebih siap dan bersemangat mengikuti pembelajaran. Tahap-tahap yang dilakukan pada Siklus I sudah dimengerti siswa. Anggota kelompok yang sudah dibagi dan tempat berdiskusi sudah pasti, siswa tidak perlu lagi mencari-cari tempat atau berebut tempat diskusi. Aktivitas motorik siswa sudah tertata pada Siklus II pertemuan pertama. Persentase aktivitas siswa paling rendah pada aspek mental activity. Aspek ini ditandai dengan siswa aktif dalam memberikan komentar atau pendapat pada tahap kesimpulan. Mengacu pada Siklus I siswa tidak memiliki catatan pribadi, pada Siklus II siswa menyiapkan catatan untuk menuliskan hasil belajar hari itu yang membuat siswa menunggu ada yang berpendapat atau guru memberikan hasil kesimpulan untuk dicatat.

Hasil belajar kognitif siswa pada Siklus II pertemuan pertama meningkat dibanding dengan Siklus I. Jumlah siswa yang tuntas KKM 2,67 sebanyak 21 atau sebesar $67,74 \%$. Kenaikan persentase ini didukung dengan kesiapan siswa yang sudah belajar di rumah sebelumnya. Siswa sudah mulai aktif bertanya jika ada hal yang belum dimengerti. Siswa mencatat sesuai dengan apa yang didengarkan dan dimengerti sendiri. Dalam lembar jawaban tes yang dikumpulkan, siswa sudah mulai mengunakan kata-kata sendiri untuk menjawab soal yang diberikan. Siswa yang satu dengan siswa yang lain cenderung berbeda dalam memberikan jawaban walaupaun kesimpulannya sama. Siswa sudah mampu menjelaskan 
dan memberikan ulasan yang lebih detail dari jawaban tes Siklus I.

Kegiatan Siklus II pertemuan kedua dilaksanakan sehari setelah Siklus II pertemuan pertama dilaksanakan. Hari Rabu, 30 Maret 2016 pukul 06.30 WIB pembelajaran Biologi dimulai. Kegiatan Siklus II pertemuan kedua dimulai dengan demonstrasi alat indra. Demonstrasi dibantu oleh siswa sebagai probandus. Kegiatan siswa lain yang tidak melakukan demonstrasi adalah mengamati apa yang dilakukan temannya.

Hasil observasi aktivitas siswa pada Siklus II pertemuan kedua memiliki persentase yang jauh lebih tinggi dari Siklus I dan Siklus II pertemuan pertama. Visual activity memiliki persentase pada Siklus II pertemuan kedua. Selain membaca, siswa juga dikondisikan untuk menyimak dan memperhatikan apersepsi guru di awal pembelajaran. Kegiatan ini mendukung siswa dalam membangun motivasi siswa dalam mengikuti pembelajaran. Aktivitas visual ini tidak lepas dari peran guru dalam mengelola kelas dan memberi instruksi pada siswa untuk memperhatikan setiap fase pembelajaran sekaligus upaya untuk menciptakan gairah belajar siswa sehingga terdorong untuk belajar dengan sungguh-sungguh.

Aktivitas tertinggi pada kegiatan Siklus I adalah motor activity sebesar $74,19 \%$, sedangkan aktivitas terrendah adalah writing activity sebesar 6,45\%. Visual activity sebesar $64,52 \%$, oral activity sebesar $61,29 \%$, emotional activity sebesar $61,29 \%$, listening activity sebesar 29,03\%, drawing activity sebesar 19,36\%, mental activity sebesar 9,68\%, dan writing activity sebesar 6,45\%.

Pada kegiatan Siklus II pertemuan pertama prosentase aktivitas siswa adalah visual activity sebesar 80,65\%, sedangkan aktivitas terrendah adalah mental activity sebesar 29,02\%. Oral activity sebesar 70,97\%, listening activity sebesar 74,20\%, writing activity sebesar 38,71\%, drawing activity sebesar $61,29 \%$, motor activity sebesar $58,06 \%$, emotional activity sebesar $67,74 \%$.

Aktivitas tertinggi pada kegiatan Siklus II pertemuan kedua adalah visual activity sebesar 96,77\%, sedangkan aktivitas terrendah adalah mental activity sebesar 29,02\%. Oral activity sebesar 70,97\%, listening activity sebesar $74,20 \%$, writing activity sebesar 38,71\%, drawing activity sebesar $61,29 \%$, motor activity sebesar 58,06\%, emotional activity sebesar $67,74 \%$.

Aktivitas siswa yang memiliki persentase terendah pada kegiatan Siklus II pertemuan kedua adalah mental activity. Rendahnya aspek mental activity dikarenakan writing activity siswa yang meningkat. Siswa yang terbiasa memiliki catatan mengadaptasi kebiasaan sebelumnya dengan penerapan sintak model STAD disertai mind mapping yang digunakan dalam penelitian. Siswa merasa tetap membutuhkan catatan pribadi seperti proses pembelajaran sebelumnya, walaupun model pembelajaran yang digunakan guru berubah.

Hasil kognitif siswa pada kegiatan Siklus II pertemuan kedua memiliki persentase tertinggi, yaitu sebesar $87,1 \%$ atau sebanyak 27 siswa yang dinyatakan tuntas. KKM 2,67 dapat dilampaui siswa berdasarkan hasil kognitif kegiatan Siklus II pertemuan kedua. Secara klasikal kelas, XI MIPA
4 sudah tuntas aspek kogntif pada kegiatan Siklus II pertemuan kedua.

Hasil analisis data aktivitas siswa yang terdiri dari delapan aktivitas menunjukkan bahwa upaya penerapan model pembelajaran STAD disertai mind mapping mampu meningkatkan aktivitas dan hasil belajar kognitif siswa. Hasil penelitian ini sesuai dengan hasil penelitian Halolo (2014) yang mengungkapkan bahwa penerapan model pembelajaran kooperatif STAD dapat meningkatkan kompetensi siswa dengan adanya kerja sama antar peserta didik dalam kelompok untuk mencapai tujuan pembelajaran.

Peningkatan aktivitas dan hasil belajar siswa cukup beralasan karena pengkonstruksian pengetahuan secara bersama-sama melalui kerja kelompok akan mendorong siswa untuk mengungkapkan pemikiran atau gagasan, melatih siswa mendengarkan pendapat orang lain dalam kelompok, dan terakhir secara bersama-sama membangun pengertian. Keberhasilan proses belajar mengajar dapat dilihat dalam motivasi belajar yang ditunjukkan oleh para siswa pada saaat melaksanakan kegiatan belajar-mengajar. Penggunaan peta konsep pada penelitian ini berupa writing activity cukup efektif dan berpengaruh pada hasil pemahaman konsep siswa. Terlihat pada diagram, peningkatan persentase writing activity dibarengi dengan peningkatan pemahamn konsep siswa.

Menulis narasi dalam bentuk catatan tidak dapat dilakukan siswa semudah siswa menulis apa yang diucapkan guru. Hal ini terbukti dalam penelitian ketika siswa tidak diberikan perintah untuk menulis catatan, dan tidak diberikan komando untuk menulis menyebabkan siswa menjadi bingung. Siswa cenderung malas atau tidak berminat untuk menulis jika tidak ada komando khusus dari guru. Selama penelitian tidak ada perintah khusus dari guru untuk membuat atau menulis catatan pribadi, hasilnya siswa yang sebelumnya terbiasa menulis menjadi pasif. Kebutuhan catatan pribadi setiap siswa berbeda-beda sesuai dengan gaya belajar yang dimiliki siswa. Pada Siklus I siswa mengungkapkan bahwa menggunakan metode mind mapping untuk pertama kali tidak mudah. Pada Siklus II siswa sudah mulai mengerti dan mampu membuat mind mapping.

Secara umum penelitian ini dapat dikatakan berhasil karena mampu meningkatkan aktivitas dan hasil belajar kognitif siswa kelas XI MIPA SMA N 6 Surakarta tahun pelajaran 2015/2016. Tanggapan siswa terhadap pelaksanaan pembelajaran juga baik, hal ini dapat terjadi karena penerapan model STAD disertai mind mapping membantu siswa untuk lebih aktif. Temuan ini berimplikasi bahwa perbaikan proses pembelajaran dan hasil belajar dapat dilakukan dengan penerapan model STAD disertai mind mapping.

\section{KESIMPULAN}

Berdasarkan hasil penelitian dapat disimpulkan bahwa: a. Terdapat peningkatan aktivitas belajar melalui Model STAD disertai Mind Mapping. b. Terdapat peningkatan pemahaman konsep melalui Model STAD disertai Mind Mapping. 
Hasil penelitian ini secara teoritis dapat dijadikan sebagai referensi dalam pengembangan penelitian tindakan kelas (PTK) lebih lanjut dalam rangka meningkatkan aktivitas dan hasil belajar siswa. Penelitian ini secara praktis dapat diterapkan pada proses pembelajaran biologi dalam rangka meningkatkan aktivitas dan hasil belajar siswa.

Guru dapat menerapkan model STAD disertai mind mapping sebagai salah satu alternatif pembelajaran biologi. Penelitian selanjutnya, terhadap aktivitas dan hasil belajar siswa menggunakan instrumen yang berbeda Mengembangkan instrumen untuk aktivitas dan hasil belajar siswa lebih cermat.

\section{DAFTAR PUSTAKA}

Arikunto, S. Suharjono., \& Supardi (2011). Penelitian Tindakan Kelas. Jakarta: Bumi Aksara.

E.Slavin, R. (2005). Cooperative Learning. Bandung : Nusa Media.

Ella, Y. (2004). Kurikulum Dan Pembelajaran. Jakarta: Pakar Raya.

Haloho, L. (2014). Perbaikan Aktivitas Belajar Biologi Siswa Melalui Penerapan Model Pembelajaran Kooperatif Tipe Stad (Student Teams Achievement Division) Pada Siswa Kelas X-3 Sma Negeri 12 Medan. Jurnal Saintech, 6 (2).

Hamid, S. (2012). Metode Edutainment. Jogjakarta: Diva Press.

Harahap, N. (2013). Penerapan Model Pembelajaran Kooperatif Tipe Stad Terhadap Hasil Belajar Kognitif, Motivasi, Dan Aktivitas Belajar Siswa Padakonsep Ekosistem Di Mtsn Model Banda Aceh. Issn 20861397. $4(2)$.

Hilman.(2014). Penerapan Pembelajaran Inkuiri Terbimbing Dengan Mind Map Terhadap Keterampilan Proses Sains Dan Hasil Belajar Ipa. Jurnal Pendidikan Sains, 2 (4)

Ristiasari,Tia .Dkk.(2012). Metode Pembelajaran Problem Solving Dengan Mind Mapping Terhadap Kemampuan Berpikir Kritis Siswa. Unnes Journal of Biology Education, 1 (3).

Samadian, Z. (2014) The Effect Of Cooperative Learning Activities On Writing Sklills Of Irinian Efl Learners. Linguistics And Literature Studies, 2 (4), 121-130

Sudjana. (1992). Metoda Statistika. Bandung :Tarsito. 